\title{
Analisis Hasil Audit Pelaporan Keuangan Dana Kampanye Peserta Pemilu Sebagai Tingkat Kepatuhan Partai Politik
}

\author{
Akuntansi \\ Dien Noviany Rahmatika \\ Fakultas Ekonomi dan Bisnis Universitas Pancasakti Tegal \\ Email: diennovi@upstegal.ac.id
}

\begin{abstract}
Abstrak
Hasil audit dalam pelaporan dana kampanye telah dipublikasikan Komisi Pemilihan Umum melalui situsnya. Audit ini meliputi semua penerimaan dan pengeluaran dana kampanye peserta pemilu. Namun, meski hasil audit dana kampanye telah diumumkan, masih banyak masyarakat yang belum bisa memahami hasil audit laporan tersebut. Masyarakat sebagai pemegang hak suara berhak mengetahui hasil audit pelaporan keuangan partai politik peserta pemilu untuk dasar pengambilan keputusan dalam melakukan pemilihan. Metode penelitian ini menggunakan penelitian deskriptif kualitatif. Penelitian ini menjelaskan secara deskriptif kepatuhan partai politik dalam melaporkan dana kampanye peserta pemilu dari kacamata akuntansi, dilihat dari waktu yang tepat dalam pelaporan, akuntabilitas dan transparansi laporan, kepatuhan partai politik dalam pengauditan pelaporan dana kampanye, dan strategi pengawasan kecurangan pelaporan dana kampanye
\end{abstract}

Kata kunci : audit kepatuhan, dana kampanye, partai politik, fraud.

\begin{abstract}
The General Election Commission has published the results of audits in campaign finance reporting through its website. This audit includes the receipt and disbursement of election participants' funds. However, even though the campaign finance audit results have been announced, there are still many people who do not yet understand the results of the audit report. The public as voting rights holders can see the financial reporting audit results of political parties participating in the election for decision-making in conducting elections. This research method uses descriptive qualitative research. This study describes descriptively political parties in reporting election campaign funds from an accounting perspective, seen from the right time in reporting, accountability, and reporting transparency, based on political parties in campaign fund reporting auditing, and campaign fund reporting fraud monitoring strategies
\end{abstract}

Keywords: compliance audit, campaign funds, political parties, fraud. 


\section{PENDAHULUAN}

Indonesia mengalami kemajuan bangsa ditandai dengan tingginya antusias masyarakat membangun negara yang menganut demokrasi. Demokrasi sendiri adalah suatu bentuk keadilan dengan partisipasi nyata dari semua elemen yang ingin ikut serta dalam membangun bangsa Indonesia. Tujuan demokrasi adalah membuat keadilan berpolitik dan mewujudkan keadilan sosial bagi seluruh rakyat Indonesia diberbagai bidang (Masyitoh, Wardhani, \& Setyanigrum, 2015). Amandemen UUD 1945 menyatakan kedaulatan sepenuhnya di tangan MPR, sebagaimana dimaksud dalam pasal 1 ayat (2) mengatakan bahwa kedaulatan tertinggi ditangan rakyat dan dijalankan berdasarkan UUD. Sekarang, wujud nyata dalam sistem demokrasi diantaranya berupa partisipasi rakyat dalam memilih wakil maupun pemimpin yang duduk dalam kursi pemerintahan. Partisipasi ini melalui penggunaan hak suara yang dipilih dalam pemilihan umum (Sugiwa, Arifah, \& Farobi, 2015).

Pemilihan umum (Pemilu) merupakan wahana kedaulatan rakyat, dengan memberi sebuah kesempatan rakyat untuk menentukan pejabat dalam pemerintahan ataupun parlemen sesuai visi, misi dan janji kampanye masing masing calon terpilih. Pemilu yang telah terselenggara di Indonesia berjumlah 11 kali dan proporsional sistem terbuka diterapkan pertamakali pada saat pemilihan legislatif 2009. Dengan sistem terbuka, rakyat tidak memilih partai politik namun memilih calon legislatif. Calon terpilih ditetapkan di suatu daerah dilakukan atas dasar perolehan suara terbanyak. (Ganguly, Al-Faraj, \& Hancock, 2017). Tentu saja, pemilihan yang dilakukan langsung maupun tidak langsung memberikan dampak dan peluang masing-masing pada setiap calon. (Sugiwa, dkk., 2015)

Peran dan fungsi partai politik dinilai fundamental dalam masyarakat demokrasi. Sebagai penghubung masyarakat dan pemerintah, partai politik merumuskan dan mengagregasi kebutuhan masyarakat. Partai politik tidak hanya di tengah rakyat, tetapi bergerak juga atas dukungan rakyat. Oleh karenanya, tergantungnya partai politik pada penyumbang dapat menjadikan partai politik berubah kepentingan perseorangan mengatasnamakan kepentingan publik. (Rahman dkk, 2011). Pada situasi seperti ini, kondisi keuangan partai politik harus diatur sebagai upaya sumbangan perseorangan dan badan usaha, hasilnya tidak menjerumuskan partai politik lupa akan posisinya sebagai institusi publik dan tetap mementingkan kepentingan rakyat (Yahya \& Mahzan, 2011). Seirama dengan pendapat Imansyah (2012) dan Kariyoto (2013) menyatakan bahwa partai politik wajib melaksanakan beberapa fungsi meliputi mediasi rakyat dan pemerintah, pencalonan kandidat, mengorganisasi kepemerintahan, mendorong akuntabilitas pada publik, pendidikan atas politik dan pengatur konflik. 
Secara administratif, sumber keuangan partai politik diatur oleh negara. Keuangan ini bisa disa didapatkan sumbangan perseorangan, perusahaan atau anggota. Karena kuantitasnya, seringkali partai politik memiliki ketergantungan pada penyumbang sehingga dapat menjadikan partai politik berubah kepentingan perseorangan mengatasnamakan kepentingan publik.

Kebijakan yang sudah berlaku di Indonesia sejak era reformasi. Terlihat pada UU No. 2/1999 dan UU No.3/1999 yang sudah dilakukan menjelang Pemilu 1999; UU No. 31/2002, UU No. 12/2003 dan UU No. 23/2003 diberlakukan menjelang Pemilu 2004; serta UU No. 2/2008, UU No. 10/2008 dan UU No. 42/2008 yang berlaku pada Pemilu 2009. Namun, segala perundangan tersebut tidak berhasil membuat partai politik memiliki sikap transparan dan akuntabilitas dalam pengelolaan keuangannya. Hal ini merupakan indikasi dan redflag partai politik dominan digerakkan oleh dana ilegal dan penyumbang besar. Meskipun demikian pemerintah terus mendorong partai politik untuk menghindari adanya kepentingan para penyumbang. Tampak dalam UU No. 2/2011 merupakan perubahan UU No. 2/2008. UU No. 2 Tahun 2011 berisi dua (2) ketentuan baru terkait bantuan keuangan partai politik yaitu: pertama, dana bantuan keuangan partai politik memprioritaskan pendidikan politik; kedua, BPK mengaudit laporan penggunaan bantuan partai politik. (Sutopo, Wulandari, Adiati, \& Saputra, 2017)

Sistem pendanaan politik yang transparan dan akuntabilitas merupakan syarat utama kepercayaan publik terhadap partai politik. Meskipun demikian, tanpa adanya dana memadai, partai politik tidak dapat menjalankan roda organisasi. Partai politik membutuhkan dana cukup besar sebagai upaya pelaksanakan fungsinya dalam wujud jembatan masyarakat dan pemerintah (Udoyono, 2012). Untuk mewujudkan azas transparansi dan akuntabilitas maka partai politik harus membuat laporan keuangan sebagai wujud good governance partai politik yang baik.

Disetiap sektor, laporan keuangan wajib dibuat sebagai perwujudan akuntabilitas suatu entitas. Transparansi dan akuntabilitas keuangan mensyaratkan adanya laporan berdasarkan standar akuntansi keuangan sesuai dengan PSAK 45 dan pedoman audit bagi partai politik (Hafild, 2008 dan Wahyuni, 2013). Tuntutan ini sebagai pertanggungjawaban nilainilai good governance bagi partai politik, dikarenakan partai politik sebagai organisasi publik. Nilai akuntabilitasnya dalam pengelolaan dan pelaporan keuangan sangat berperan membantu pelaksanaan tata kelola partai politik yang baik (good political party governance).

Salah satu wujud laporan keuangan partai politik adalah dengan keterbukaan pada dana kampanye pemilu. Audit dana kampanye diantaranya melalui pelaporan dana masuk 
dan keluar dari rekening khusus pasangan calon yang nantinya akan diaudit oleh auditor. Auditor yang diamanahkan lalu ditetapkan KPU dan KAP (Kantor Akuntan Publik) sesuai PKPU Nomor 5 Tahun 2017 bab 4 "Perikatan Audit” Pasal 43 ayat (1) dan (5) menyatakan "Akuntan Publik akan melakukan audit wajib dengan dilengkapi surat tugas KAP yang sudah ditetapkan KPU untuk sebagaimana melakukan audit yang dimaksud dalam ayat (1) bertanggung jawab atas laporan hasil audit”.

Dari latar belakang diatas maka peneliti merumuskan penelitian ini dengan bagaimana membahas hubungan tingkat kepatuhan partai politik dalam pengauditan dana kampanye dilihat dari waktu yang tepat dalam pelaporan, akuntabilitas dan transparansi laporan, kepatuhan partai politik dalam pengauditan pelaporan dana kampanye, dan bagaimana strategi pengawasan kecurangan pelaporan dana kampanye

\section{TINJAUAN PUSTAKA}

\section{Partai Politik}

Partai politik merupakan suatu wadah organisasi yang dapat bersifat nasional dan dibentuk oleh sekelompok masyarakat Indonesia melalui sukarela berdasarkan kesamaan kehendak dan cita-cita untuk perjuangan dan kepentingan politik serta memelihara keutuhan Negara Indonesia berdasarkan Pancasila dan Undang-Undang Dasar Negara Republik Indonesia Tahun 1945. (Susanto \& Iqbal, 2020).

\section{Dana Kampanye}

Pasal 7 ayat (1),(2), dan (3) PKPU No. 5 tahun 2017 tentang Dana Kampanye mengatur pembatasan jumlah dana kampanye sebagai berikut:

1. Dana Kampanye yang berasal dari Partai Politik atau Gabungan Partai Politik sebagaimana dimaksud dalam Pasal 5 ayat (2) nilainya paling banyak Rp750.000.000,00 (tujuh ratus lima puluh juta rupiah) setiap Partai Politik selama masa Kampanye.

2. Dana Kampanye yang berasal dari sumbangan pihak lain perseorangan sebagaimana dimaksud dalam Pasal 5 ayat (3) huruf a, nilainya paling banyak Rp75.000.000,00 (tujuh puluh lima juta rupiah) selama masa Kampanye.

3. Dana Kampanye yang berasal dari sumbangan pihak lain kelompok atau badan hukum swasta sebagaimana dimaksud dalam Pasal 5 ayat (3) huruf b dan huruf c, nilainya paling banyak Rp750.000.000,00 (tujuh ratus lima puluh juta rupiah) selama masa Kampanye. 
Melihat tuntutan dana kampanye yang besar, membuat peserta pemilu berusaha menyiapkan dana. Namun dana yang harus dikumpulkan memunculkan berbagai persoalan baru, yakni mengenai absahan dana, ataupun pengaruh dana yang disumbangkan kepada tanggungjawab peserta pemilu (Anjalline, Anggraini, \& Indrayati, 2014)

\section{Peraturan Komisi Pemilihan Umum}

Partai Politik peserta Pemilu wajib melaporkan daftar penyumbang dan jumlah sumbangan sebelum lima belas hari dan tiga puluh hari setelah pemilihan umum pada Mahkamah Agung Republik Indonesia. Peraturan Komisi Pemilihan Umum selain mengatur tugas serta tanggung jawab peserta, mengatur juga kewajiban akuntan publik yang mengaudit dana kampanye peserta Pemilu. KPU mengeluarkan Peraturan Komisi Pemilihan Umum Republik Indonesia No. 12 Tahun 2020 tentang Perubahan atas Peraturan Komisi Pemilihan Umum (PKPU) No. 5 Tahun 2017 tentang Dana Kampanye Peserta Pemilihan Gubernur dan Wakil Gubernur, Bupati, dan Wakil Bupati dan/atau walikota dan wakil walikota

\section{Standar Auditing.}

Menurut Ikatan Akuntan Indonesia (IAI) Audit yang dilakukan auditor dapat berkualitas jika sudah memenuhi standar auditing dan pengendalian mutu. Akuntan publik juga berpedoman pada Standar Profesional Akuntan Publik (SPAP) yang sudah ditentukan oleh Ikatan Akuntan Indonesia (IAI) yang merupakan standar auditing. Standar auditing sendiri terdiri atas standar umum, standar pekerjaan lapangan dan standar pelaporan (SPAP \& Institut Akuntan Publik, 2011).).

\section{Audit Dana Kampanye}

Audit atas penggunaan dana kampanye adalah bagian audit kepatuhan (Compliance audit) yang meliputi kegiatan pemeriksaan bukti dimana penyesuaian antara aktivitas yang dilakukan dengan peraturan standar. Dalam mengaudit dana kampanye melibatkat tiga pihak yaitu Komisi Pemilihan Umum (KPU) dan Kantor Akuntan Publik (KAP). Informasi akuntansi dapat berupa pelaporan hasil audit yang diperlukan publik dalam organisasi atau individu langsung dengan masyarakat (Fatkhurohman, 2011). Laporan dana kampanye yang harus dilaporkan terdiri atas 1) Laporan Awal Dana Kampanye (LADK); 2) Laporan Penerimaan Sumbangan Dana Kampanye (LPSDK); 3) Laporan Penerimaan dan Pengeluaran Dana Kampanye (LPPDK). 


\section{METODE PENELITIAN}

Ditinjau pada metode, penelitian ini mengarah pada penelitian deskriptif kualitatif. Penelitian ini dimaksudkan untuk memahami fenomena yang dialami subjek penelitian, contohnya persepsi perilaku, tindakan, motivasi dan sebagainya secara deskriptif dan holistik dalam bentuk bahasa dan kata pada suatu konteks alamiah khusus dan memanfaatkan berbagai metode alamiah (Sugiyono, 2016). bahwa penelitian kualitatif berusaha mengonstruksi realita dan memahami maknanya, olehnya penelitian ini memperhatikan proses, peristiwa dan otensitas. Dasarnya penelitian kualitatif ini menghadirkan nilai eksplisit pada situasi terbatas dengan melibatkan subjek berjumlah sedikit. (Sugiyono,2016:52)

Data penelitian yang dilakukan adalah data dapat diperoleh atas hasil catatan lapangan, wawancara dan juga dokumentasi dalam mengorganisasikan ke kategori, memilih yang penting dan membuat kesimpulan sehingga mudah dipahami oleh orang lain merupakan analisis data. (Sugiyono, 2016:244)

\section{PEMBAHASAN}

Peneliti akan menyampaikan beberapa bagian diharapkan sesuai dengan kaitannya dengan masalah yang diteliti. Adapun nantinya dipaparkan ini meliputi penelitian pada dana kampanye partai politik.

\section{Periode Waktu Pelaporan Dana Kampanye}

Waktu pelaporan dana kampanye dalam penelitian ini diperoleh dari laporan dana kampanye yang sudah dikumpulkan. Bastian (2007:169) Laporan dana kampanye pasangan Calon Presiden dan Wakil Presiden harus disampaikan ke KPU selambatnya 3 (tiga) hari usai pemungutan suara. Indikator unsur yang mencakup kepatuhan ketepatan laporan wajib dipenuhi yakni, Laporan Penerimaan Sumbangan Periode 1 dan Laporan Penerimaan Sumbangan Periode II dengan prosedur pelaporan awal dana kampanye dan pembukaan rekening khusus dana kampanye wajib dilampirkan dalam jangka waktu 14 hari sebelum kampanye rapat umum sesuai perundangan Pemilihan Umum Presiden dan Wakil Presiden; (Ma'mun \& Kosandi, 2020)

\section{Akuntabilitas Dan Transparansi Pelaporan Keuangan Partai Politik}

Kriteria yang tercakup dalam pelaporan dana kampanye diterapkan dalam Peraturan KPU No 5 Tahun 2017 yakni, Cakupan Umum, Cakupan Penerimaan dan Pengeluaran dana kampanye, Cakupan Laporan Awal Dana Kampanye (LADK) dan Laporan Penerimaan Sumbangan Dana Kampanye (LPSDK). Menurut peneliti Adiwirya (2015) dan Patton (2011) 
menyatakan bahwa transparansi dan akuntabilitas adalah suatu konsep berkaitan erat, hal ini disebabkan transparansi tak banyak manfaat tanpa lengkapnya akuntabilitas dalam proses pembuatan laporan keuangan yang berupa keterbukaan atas kegiatan pengelolaan dana. Tujuan ini sebagai penjelasan suatu pertanggungjawaban kepada masyarakat secara transparan supaya masyarakat mengetahui bagaimana peserta pemilu organisasi nirlaba partai politik menjalankan anggaran dananya. Berdasarkan perolehan hasil dokumen wawancara disimpulkan bahwasanya partai politik menganggap dirinya sudah menerapkan akuntabilitas pengelolaan laporan keuangan dana sesuai peraturan yang telah dibentuk secara seksama. (Adiwirya \& Sudana, 2015).

\section{Kepatuhan Partai Politik Dalam Pengauditan Pelaporan Dana Kampanye}

Hasil pengamatan menyebutkan kepatuhan partai politik dalam pengauditan dana kampanye dimulai dari transaksi dan penginformasian laporan keuangan dinilai telah transparansi dan akuntabel. Penyajian laporan keuangan dilakukan dengan menyesuaikan standar yang telah ditetapkan yaitu dengan menggunakan PSAK 45. Kelemahan yang sering ditemukan adalah adanya keterbatasan pengetahuan oleh pengelola laporan keuangan. Partai politik sudah merasa berusaha mengkaji laporan keuangan sebaik mungkin untuk pengguna laporan keuangan supaya dapat dipahami dan mudah diakses informasi untuk masyarakat yang membutuhkannya, akan tetapi belum sesuai dengan aturan baku dalam audit. Sebagai contoh, partai politik harus mencantumkan dana iuran anggota dan bantuan keuangan pemerintah sebagai dana hibah yang menjadikan keharusan partai politik menyajikan laporan keuangannya pada pihak internal dan pemerintah selaku pemberi dana hibah (Halim dan Kusufi, 2012:414).

Secara umum, pemeriksaan dana kampanye merupakan suatu audit khusus yang didalamnya meliputi tiga (3) pihak yakni, KPU (Komisi Pemilihan Umum), KAP (Kantor Akuntan Publik) dan partai politik peserta pemilu. Harus diketahui jika dilihat dari sisi KAP, maka objek audit dalam pengauditan adalah Partai Politik dan kliennya yaitu KPU. Sedangkan pedoman pengauditan dana kampanye yang dipakai , mencakup

1. Kualifikasi standar KAP, yaitu merupakan standar baku bagi KPU yang menyelenggarakan Pemilihan dalam melakukan seleksi/pengadaan KAP

2. Panduan Audit KAP, yaitu panduan bagi Akuntan Publik dalam audit Dana Kampanye dan merupakan prosedur yang disarankan untuk dilakukan dalam melaksanakan audit Dana Kampanye 
3. Hasil laporan pelaksanaan audit, yaitu Laporan Hasil pekerjaan audit yang disampaikan kepada KPU

Implementasi pedoman dana kampanye bertujuan mewujudkan laporan yang transparan dan akuntabel, dimulai dari proses pencatatan, pengelolaan, dan pelaporan dana kampanye dalam meningkatkan kepercayaan publik atas penyelenggaraan pemilu yang langsung, umum, bebas, rahasia, jujur, dan adil. Peraturan KPU RI No. 5 tahun 2017 terbaru menjabarkan audit pada LPPDK serta laporan terkait dilakukan oleh KAP adalah audit yang dilaksanakan menggunakan bentuk perikatan prosedur yang disepakati.

\section{Strategi Pengawasan Kecurangan Pelaporan Dana Kampanye}

Untuk menghindari adanya kecurangan pada pelaporan dana kampanye maka sesuai dengan aturan Pasal 74 UU Nomor 10 Tahun 2016 tentang Pilkada serta Peraturan KPU (PKPU) Nomor 5 Tahun 2017. Badan Pengawas Pemilu harus menggandeng Pusat Pelaporan dan Analisis Transaksi Keuangan (PPTATK) terkait hal ini. Strategi yang dilakukan dalam menindak pelanggaran praktik politik uang dan pengawasan dana kampanye pemilihan dengan melakukan pengawasan dana kampanye tidak hanya terhadap sumbangan berbentuk uang saja, tetapi terhadap sumbangan barang dan jasa yang digunakan untuk berkampanye sesuai dengan Pasal 6 Ayat (1) PKPU Nomor 5 Tahun 2017 yang menyebutkan bentuk dana kampanye. Bawaslu juga harus melihat secara rinci akun bank yang dibuat untuk rekening khusus dana kampanye (RKDK), juga saldo awal dan sumber awal pembukaan rekening dan mengisi atik formulir yang sudah ditetapkan KPU.

Strategi pengawasan lainnya, yaitu dengan melakukan pengecekan mengenai sumbangan dana kampanye yang melebihi batas. Kemudian penelusuran terhadap penyumbang dana kampanye untuk memastikan kebenaran dan kesesuaian identitas penyumbang. Dengan adanya hal ini, harapannya tidak ada afiliasi antara Kantor Akuntan Publik (KAP) dengan peserta pemilihan saat pengecekan laporan audit kampanye. Pemilihan KAP ini penting dengan cara melihat catatan integritas dari Institut Akuntan Publik Indonesia (IAPI) harus dimiliki oleh KAP yang telah ditunjuk, untuk mempertahankan kredibelitas hasil audit.

\section{KESIMPULAN}

Pelaporan dana kampanye harus dilakukan oleh Partai Politik sesuai dengan peraturan perundang undangan. Pelaporan ini juga dapat diartikan sebagai tingkat kepatuhan partai politik untuk diaudit oleh Kantor akuntan Publik. Hasil audit pada partai politik mencakup dana yang masuk baik berupa uang atau barang. Pertanggungjawaban pengelolaan keua- 
ngan partai politik dinilai ketepatan waktu pelaporan dan kebenaran isi laporan. Sebagai upaya pelaksanaan peraturan KPU N0. 12 tahun 2020 perlu didukung kader yang berpendidikan cukup dan berkompetensi di bidang akuntansi dalam merancang anggaran laporan dana kampanye sebagaimana dimaksudkan peraturan tersebut.

Peraturan dana kampanye juga bertujuan untuk memastikan bahwa partai politik peserta pemilu benar menggunakan dana kampanye yang sah menurut undang-undang yang berlaku. Dan tak kalah pentingnya yaitu untuk menguji akuntabilitas dan transparansi partai politik dalam kaitannya pertanggungjawaban laporan keuangan dana kampanye yang sesuai etika dan peraturan perundang-undangan. Strategi agar tidak terjadi kecurangan pelaporan dana kampanye adalah dengan melakukan audit secara komprehensif memeriksa rekening khusus dana Kampanye dan badan pengawas pemilu mencocokan segala pelaporan dengan Pusat Pelaporan dan Analisis Transaksi Keuangan. Tentu saja, pelaporan yang dilakukan harus sesuai dengan standar akuntansi yang berlaku yaitu PSAK 45.

\section{SARAN}

KPU, KPUD dan KAP sebaiknya melakukan kesepakatan dalam menetapkan standar dalam penyusunan kontrak prosedur audit. Dengan dibuat kontrak prosedur audit yang sesuai dengan kondisi partai politik maka objek audit dan cakupan kerja akuntan publik sebagai auditor dapat lebih terukur. Partai Politik sebaiknya mempunyai staf khusus akuntansi dengan latar belakang pendidikan Akuntansi ataupun Keuangan dengan harapan dapat membuat laporan dana kampanye yang akuntabel. Hasil audit yang baik tentu saja akan memperbaiki laporan partai politik sehingga tidak terjadi salah saji yang pelaporannya.

\section{DAFTAR PUSTAKA}

Adiwirya, Muhammad Fidiansyah. (2015). Akuntabilitas, Transparansi dan Anggaran Berbasis Kinerja Pada Satuan Kerja Perangkat Daerah Kota Denpasar. Jurnal Akuntansi. 11(2): 611-628

Anjalline, I., Anggraini, R. A. R., \& Indrayati, R. (2014). Pengaturan Dana Kampanye Pemilihan Umum sebagai Tanggung Jawab Calon Anggota Legislatif Berdasarkan Undang - undang No. 8 Tahun 2012 tentang Pemilihan Umum Anggota DPR, DPD, dan DPRD. Jember: Universitas Jember

Bastian, Indra. (2007). Akuntansi Yayasandan Lembaga Publik: Suatu Pengantar. Jakarta: Erlangga

Fatkhurohman, F. (2011). Mengukur Kesamaan Paham Demokrasi Deliberatif, Demokrasi Pancasila Dan Demokrasi Konstitusional. Jurnal Konstitusi. 
Ganguly, R., Al-Faraj, M., \& Hancock, G. (2017). Introducing scenario based audit - A risk based approach to auditing. SPE Middle East Oil and Gas Show and Conference, MEOS, Proceedings. https://doi.org/10.2118/183896- ms

Hafild, Emmy. (2008). Laporan Studi: Standar Akuntansi Keuangan Khusus Partai Politik. Jakarta: Transparency Internasional Indonesia.

Halim, Abdul dan Muhammad Syam Kusufi. (2017). Teori, Konsep dan Aplikasi Akuntansi Sektor Publik. Jakarta: Salemba Empat.

Imansyah, Teguh. (2012). Regulasi Partai Politik dalam Mewujudkan Penguatan Peran dan Fungsi Kelembagaan Partai Politik (Regulatory Political Parties to Realize Role and Function of Strengthening Institutional Political Parties). Jurnal Rechts Vinding, Media Pembinaan Hukum Nasional. 1(3): 375-395

Iqbal, Mohamad. (2016). Kedudukan Partai Politik dalam Menerima Bantuan Keuangan Parpol. E-Jurnal Katalogis. 4(6): 1-11.

Juliestari, Mayki Ayu. (2018). Pengungkapan Pertanggungjawaban Keuangan Partai Sebagai Dasar Good Political Party Governance. Skripsi. UIN Alauddin Makassar

Kariyoto, K. (2013). Akuntansi Partai Politik. El Muhasaba: Jurnal Akuntansi. https://doi.org/10.18860/em.v2i2.2362

Kariyoto. (2013) Akuntansi Partai Politik. El-Muhasaba: Jurnal Akuntansi. 2(2): 1-12.

Ma'mun, A. R., \& Kosandi, M. (2020). Politik Pendanaan Kampanye dalam Pemilihan Presiden 2019. LITERATUS. https://doi.org/10.37010/lit.v2i2.93

Masyithoh, N. D. (2007). Kebijakan Pemerintah Daerah dalam Pemberdayaan Ekonomi Perempuan Sebagai perwujudan Ekonomi Kerakyatan (Studi Kelompok Wanita Tani Ngaliyan Kecamatan Limpung Kabupaten Batang). Jurnal Law Reform Pembaharuan Hukum, 3(2).

Patton. (2011). Accountability and Government Financial Reporting. Financial, Accounting, and management. Autumn. 8(3): 165-180.

Peraturan Komisi Pemilihan Umum Nomor 24 Tahun 2013.Pedoman Audit Laporan Dana Kampanye Peserta Pemilihan Umum Anggota Dewan Perwakilan Rakyat, Dewan Perwakilan Daerah, Dewan Perwakilan Rakyat Daerah. Jakarta: Komisi Pemilihan Umum.

Peraturan Komisi Pemilihan Umum Republik Indonesia No. 12 Tahun 2020 tentang Perubahan atas Peraturan Komisi Pemilihan Umum (PKPU) No. 5 Tahun 2017 tentang Dana Kampanye Peserta Pemilihan Gubernur dan Wakil Gubernur, Bupati, dan Wakil Bupati dan/atau walikota dan wakil walikota

Peraturan KPU Nomor 17 Tahun 2014. Pedoman Pelaporan Dana Kampanye Peserta Pemilihan Umum Anggota Dewan Perwakilan Rakyat, Dewan Perwakilan Daerah, dan Dewan Perwakilan Rakyat Daerah. Jakarta : Komisi Pemilihan Umum 
Rahman, Muh. Akil., Veri Junaidi., Gunadjar., Syamsuddin Alimsyah., Andi Nuraini., Titi Anggaraini., Lia Wulandari., Heru Gutomo dan Ahmad Anfasul Marom. (2011) Anomali Keuangan Partai Politik Pengaturan dan Praktek. Cetakan pertama. Jakarta: Kemitraan bagi Pembaruan Tata Pemerintahan.

SPAP, \& Institut Akuntan Publik. (2011). Standar Profesional Akuntan Publik (SPAP). In Pernyataan Standar Auditing No. 4.

Sugiwa, Iwan, dkk. (2015). Analisa Tingkat Kepatuhan Pelaporan Dana Kampanye Partai Politik Peserta Pemilu Berdasarkan Hasil Audit Laporan Dana Kampanye Di Provinsi Bali Pada Pemilu Legislatif 2014. Jurnal Ekonomi Dan Bisnis, 14(1): 3540.

Sugiyono. (2016). Metode Penelitian Bisnis. Cetakan ke-15. Penerbit Cv. Alvabeta. Bandung

Supriyanto, Didik dan Wulandari, Lia. (2012) Bantuan Keuangan Partai Politik Metode Penetapan Besaran, Transparansi dan Akuntabilitas Pengelolaan. Cetakan Pertama. Jakarta: Yayasan Perludem.

Udoyono, Kodar. (2012) E-procurement dalam Pengadaan Barang dan Jasa untuk Mewujudkan Akuntabilitas di Kota Yogyakarta. Jurnal Studi Pemerintahan: Journal of Government and Politics. 3(1): 1-10.

Undang-undang No.7 Pasal 327 Tahun 2017 Tentang Dana Kampanye Pemilu

Wahyuni, Salamah. (2013). Konsentrasi Partai Politik dan Opini Laporan Keuangan Daerah:

Kegagalan Resep Atau Substansi?. Jurnal Siasat Bisnis. 17(1): 107-116. 